UDK 537.86:52.7+58.027

DOI 10.37279/2413-1725-2020-6-3-56-62

\title{
CHARACTERIZATION OF ESSENTIAL OIL ACCUMULATION IN SOME PLANTS OF LAMIACEAE FAMILY
}

\author{
Bulavin I. V., Feskov S. A., Brailko V. A., Mitrofanova I. V. \\ Federal State Funded Institution of Science "The Labour Red Banner Order Nikita Botanical \\ Gardens - National Scientific Center of the RAS”, Crimea, Russia \\ E-mail: labgennbs@yandex.ru
}

\begin{abstract}
Vegetative and generative organs of some Lamiaceae plants were investigated. It was shown that accumulation of inclusion with essential oil inside glandular trichomes and internal tissues of vegetative and generative organs varied with maximal amount in the flowers. Also, dependence in amount of essential oil from species was estimated.

Keywords: Lamiaceae, plant organs, anatomy, essential oil accumulation.
\end{abstract}

\section{INTRODUCTION}

Essential oil plants are renewable source of raw materials used in medicine (phytorehabilitation, aromatherapy and etc.) and the production of perfumes and cosmetics [1]. In the Nikita Botanical Gardens (NBG), the gene pool collection of aromatic and medicinal plants is represented by different species, subspecies, forms, cultivars and hybrids. Their selection breeding, firstly, based on high essential-oil content and its corresponding quality for different purposes usage [2]. It is well known that essential oil accumulated predominantly in generative organs, especially in flowers. At the same time other vegetative organs are also characterized by presence of essential oil in different amounts [3]. Due to, essential oil analysis as well as investigation of genetic mechanisms involved in essential oil production are very necessary and perspective [4]. However, comprehensive analysis of different wild species, cultivars and forms is relevant as well [5]. Therefore, the objective of the presented study was to investigate the plant organ anatomy with regard to their accumulation of essential oil.

\section{MATERIALS AND METHODS}

Plants of Lamiaceae family (Lavandula angustifolia Mill., Lavandula x intermedia Emeric ex Loisel cv. Temp (L. angustifolia cv. Record $\times$ L. latifolia Medic.), Thymus mastichina L. cv. Svetliachok, Thymus vulgaris L. cv. Fantazia, Thymus striatus Vahl. cv. Jubileiniy) grown ex situ in the collection plot of the Nikita Botanical Gardens were used for the investigation.

For the anatomical studies, plant organs were excised and processed on freezing microtome (MZ-2, Ukraine) equipped with lab cooling system OL-ZSO 30 (Inmedprom, 
Russian Federation). Sections were stained with methylene blue and examined using CX41 light microscope (Olympus, Japan) equipped with SC 50 camera (Olympus, Germany) and CellSens Imaging Software version 1.17. Inclusion square with essential oils was determined on sections. The content of essential oil was analyzed by hydrodistillation on Ginsberg devices [6] with subsequent measurement of its volume. Data were analyzed statistically with PAST software [7].

\section{RESULTS AND DISCUSSION}

The investigated cultivars belonged to different species, however, they had common anatomical features. Stems were oval or tetragonal in shape, with epidermis, different collenchyma cell layers, chlorenchyma, cambium, vascular bundles and parenchyma cells. Inflorescence axes had rib in the corners or in the interspaces, internal tissues were similar to stems. Leaf blades with ground tissues were characterized by differentiated mesophyll with midrib, veins inside and mechanical tissues. Bracts had anatomy similar to leaf or mesophyll was homogenous. Calyxes also were with homogenous mesophyll (Fig. 1).

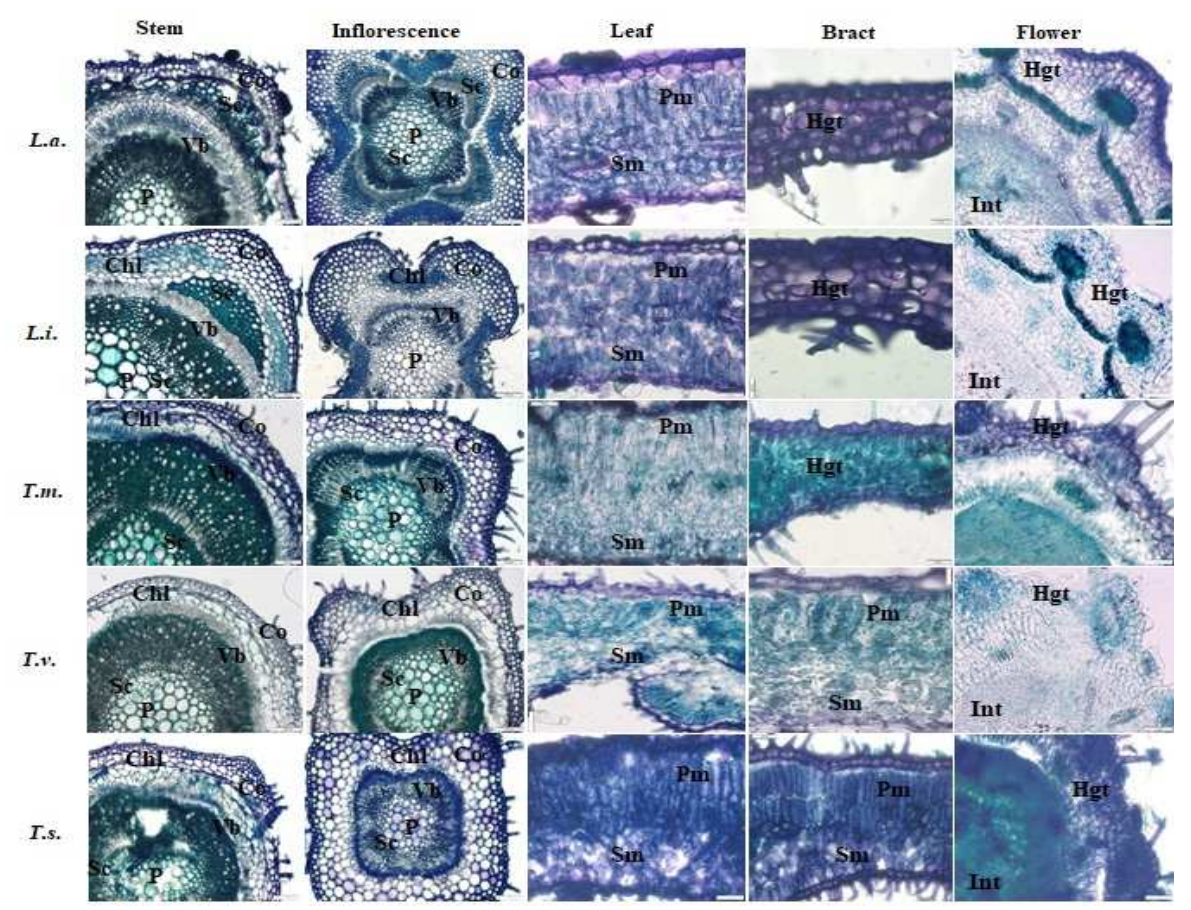

Fig. 1. Transversion section fragments of some Lamiaceae species organs: L.a. L. angustifolia, L.i. - L. intermedia cv. Temp, T.m. - T. mastichina cv. Svetliachok, T.v. T. vulgaris cv. Fantazia, T.s. - T. striatus cv. Jubileiniy, Co - collenchyma, Chl chlorenchyma, Sc - sclerenchyma, Vb - vascular bundle, P - pith, Pm - palisade mesophyll, Sm - sponge mesophyll, Hgt - homogenous tissue, Int - internal tissues of the flower structures (methylene-blue staining). 
On ground tissues of all investigated organs, non-glandular and glandular trichomes were revealed. Their typical forms presented in Fig. 2. It should be noted that glandular trichome types and their ratio varied depending on organs and species.

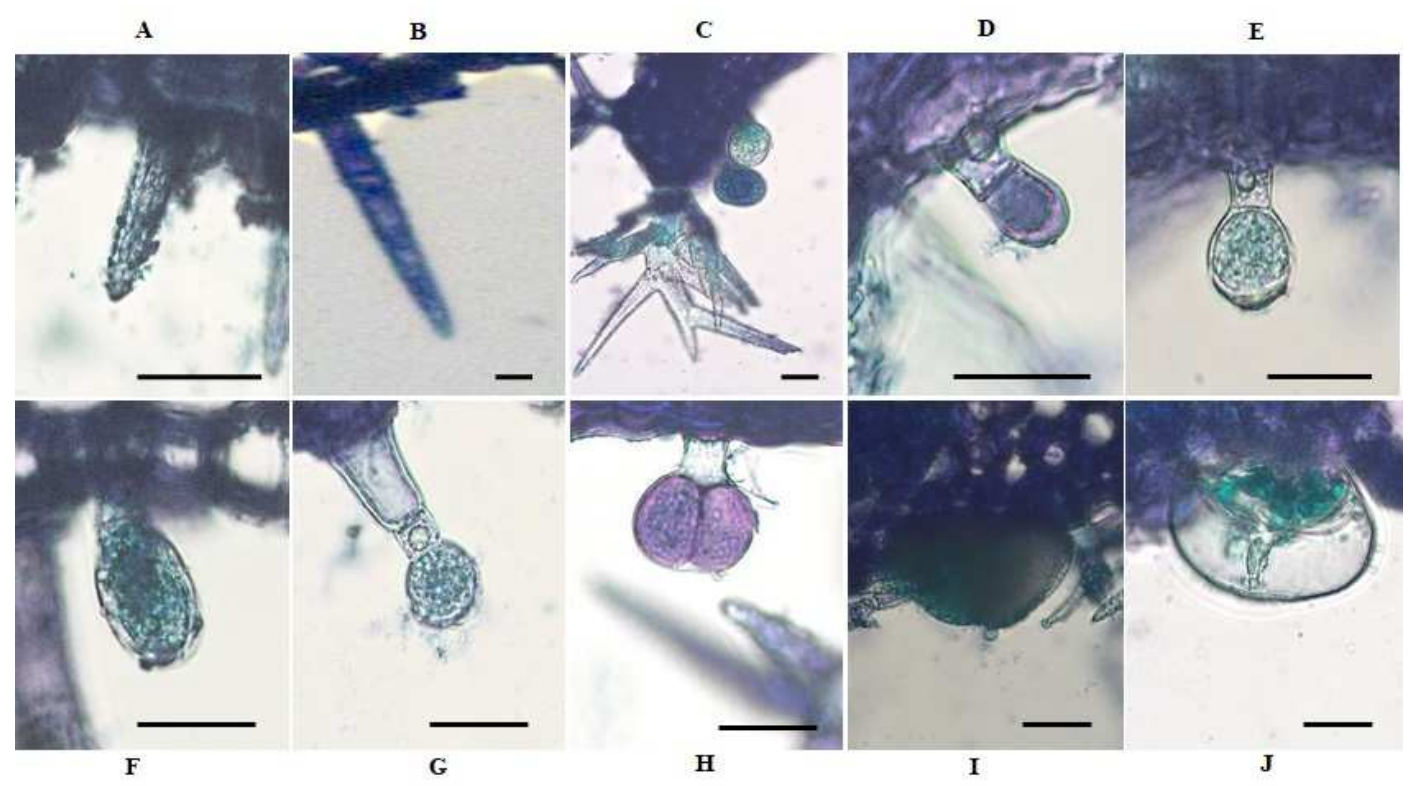

Fig. 2. Types of the non-glandular (A-C) and glandular (D-J) trichomes on ground tissues of Lamiaceae species: A - unicellular trichome, B - bicellular trichome, $\mathrm{C}$ - branched trichome, D - glandular trichomes with one stalk and one cell, E - capitate glandular trichomes with one stalk cell and unicellular ovate head, F - capitate glandular trichomes with one stalk cell and unicellular ellipsoidal head, $\mathrm{G}$ - glandular trichome with stalk, neck and round secretory cell, $\mathrm{H}$ - capitate glandular trichome with one stalk cell and bicellular ovate head, I - peltate type of glandular trichome without subcuticular cavity, $\mathbf{J}$ - peltate type of glandular trichome with subcuticular cavity (methylene-blue staining, bars $-20 \mu \mathrm{m})$.

Investigation of essential oil accumulation with anatomical method showed the presence of inclusion in glandular structures, especially in trichomes with round head. In stems, inclusions were revealed, predominantly, in chlorenchyma cells, as well as in collenchyma and vascular bundles. In the leaf blades and bracts, inclusions were detected in epidermal cell, palisade, spongy mesophyll and homogenous tissues. Higher accumulation of essential oil was presented in calyxes and internal tissues of the flower anatomical structures (Fig. 3). Their squares varied from species to species and from organ to organ (Table 1). Essential oil accumulation of thyme cultivars also was investigated biochemically. Our data showed that leaves of different cultivars accumulated essential oil from 19 to $39 \%$ and from 17 to $34 \%$ for fresh and dry weight, respectively (Table 2). High amount of essential oil (61-81\% and 66-83\%) was synthesized in the inflorescences. 


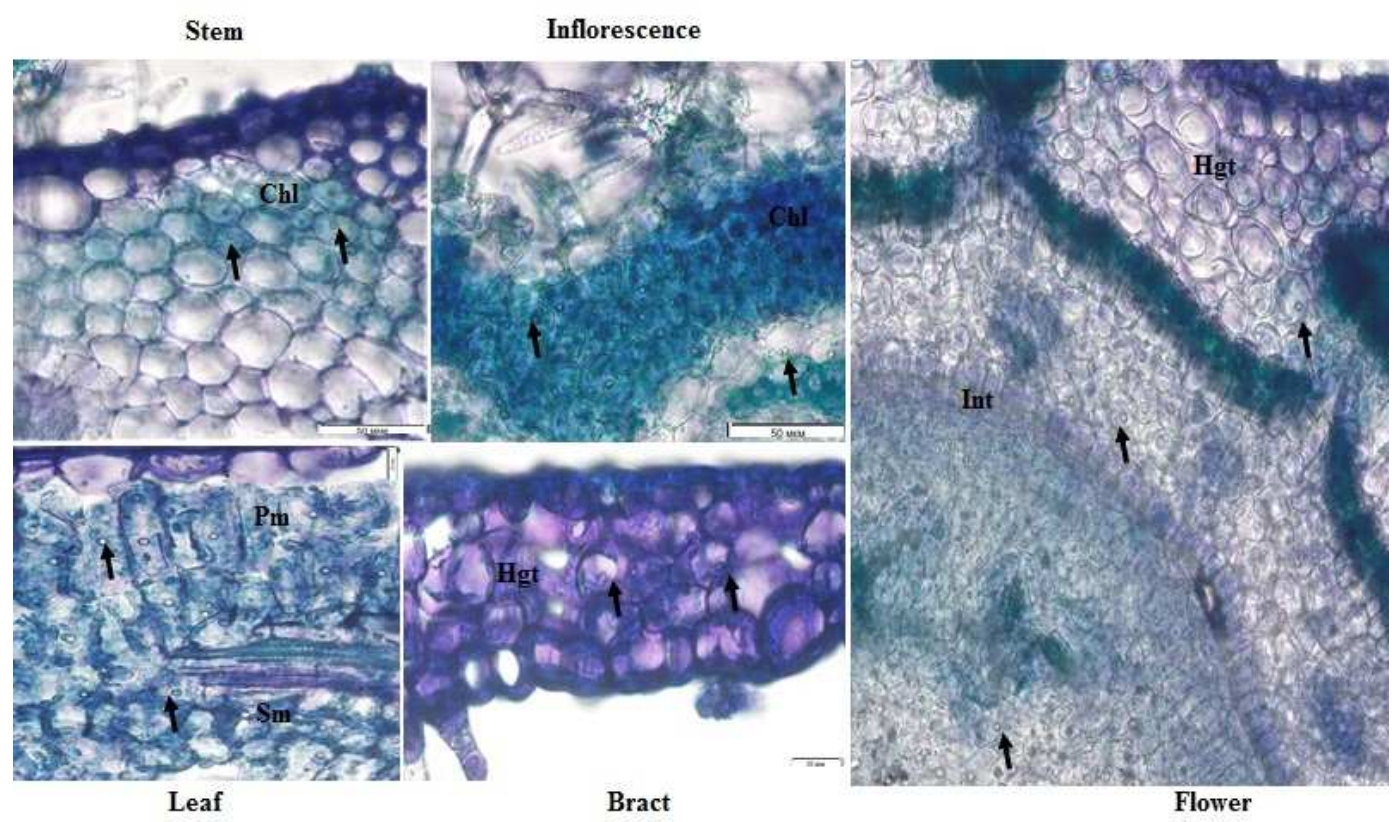

Fig. 3. Transversion section fragments of Lavandula angustifolia organs with essential oil inclusions: Chl - chlorenchyma, Pm - palisade mesophyll, Sm - sponge mesophyll, Hgt - homogenous tissue, Int - internal tissues of the flower structures (methylene-blue staining).

Table 1

Squares of the inclusions with essential oil in plant organs of Lamiaceae species

\begin{tabular}{|c|c|c|c|c|c|c|c|c|c|c|}
\hline \multirow{2}{*}{$\begin{array}{c}\text { Organ } \\
\text { Species }\end{array}$} & \multicolumn{2}{|c|}{ Stem } & \multicolumn{2}{|c|}{ Inflorescence } & \multicolumn{2}{|c|}{ Leaf } & \multicolumn{2}{|c|}{ Bract } & \multicolumn{2}{|c|}{ Flower } \\
\hline & $\begin{array}{l}\text { Min/ } \\
\text { Max }\end{array}$ & $\mathbf{M} \pm \mathbf{m}$ & $\begin{array}{l}\text { Min/ } \\
\text { Max }\end{array}$ & $\mathbf{M} \pm \mathbf{m}$ & $\begin{array}{l}\text { Min/ } \\
\text { Max }\end{array}$ & $\mathbf{M} \pm \mathbf{m}$ & $\begin{array}{l}\text { Min/ } \\
\text { Max }\end{array}$ & $\mathbf{M} \pm \mathbf{m}$ & $\begin{array}{l}\text { Min/ } \\
\text { Max }\end{array}$ & $\mathbf{M} \pm \mathbf{m}$ \\
\hline & \multicolumn{10}{|c|}{$\left(\mu \mathrm{m}^{2}\right)$} \\
\hline L. angustifolia & $\begin{array}{l}4.59 / \\
16.47\end{array}$ & $\begin{array}{c}10.67 \pm \\
1.02\end{array}$ & $\begin{array}{l}3.63 / \\
14.14\end{array}$ & $\begin{array}{l}7.55 \pm \\
0.66\end{array}$ & $\begin{array}{l}4.26 / \\
32.4\end{array}$ & $\begin{array}{l}15.1 \pm \\
1.63\end{array}$ & $\begin{array}{l}1.12 / \\
19.05\end{array}$ & $\begin{array}{l}6.82 \pm \\
1.17\end{array}$ & $\begin{array}{l}2.26 / \\
16.86\end{array}$ & $\begin{array}{l}7.01 \pm \\
0.95\end{array}$ \\
\hline $\begin{array}{l}\text { L. intermedia } \\
\text { cv. Temp }\end{array}$ & $\begin{array}{l}1.86 / \\
15.54\end{array}$ & $\begin{array}{c}4.91 \pm \\
0.71\end{array}$ & $\begin{array}{l}3.53 / \\
25.14\end{array}$ & $\begin{array}{c}10.32 \pm \\
1.34\end{array}$ & $\begin{array}{l}2.29 / \\
16 / 48\end{array}$ & $\begin{array}{c}8.67 \pm \\
0.97\end{array}$ & $\begin{array}{l}5.48 / \\
24.34\end{array}$ & $\begin{array}{c}14.06 \pm \\
1.68\end{array}$ & $\begin{array}{l}6.34 / \\
34.61\end{array}$ & $\begin{array}{c}14.53 \pm \\
1.8\end{array}$ \\
\hline $\begin{array}{c}\text { T. mastichina } \\
\text { cv. } \\
\text { Svetliachok }\end{array}$ & $\begin{array}{l}1.94 / \\
8.97\end{array}$ & $\begin{array}{l}3.91 \pm \\
1.05\end{array}$ & $\begin{array}{l}1.51 \pm \\
6.36\end{array}$ & $\begin{array}{c}3.58 \pm \\
0.5\end{array}$ & $\begin{array}{l}9.56 / \\
31.04\end{array}$ & $\begin{array}{c}21.2 \pm \\
1.32\end{array}$ & $\begin{array}{l}2.54 / \\
14.87\end{array}$ & $\begin{array}{l}7.06 \pm \\
1.33\end{array}$ & $\begin{array}{l}1.45 / \\
8.25\end{array}$ & $\begin{array}{l}3.14 \pm \\
0.34\end{array}$ \\
\hline $\begin{array}{l}\text { T. vulgaris } \mathrm{cv} . \\
\text { Fantasia }\end{array}$ & $\begin{array}{l}1.53 / \\
6.21\end{array}$ & $\begin{array}{c}3.76 \pm \\
0.35\end{array}$ & $\begin{array}{l}2.97 / \\
10.44\end{array}$ & $\begin{array}{c}5.77 \pm \\
0.8\end{array}$ & $\begin{array}{l}8.61 / \\
30.97\end{array}$ & $\begin{array}{l}20.23 \pm \\
1.27\end{array}$ & $\begin{array}{l}6.13 / \\
35.92\end{array}$ & $\begin{array}{l}14.52 \pm \\
1.49\end{array}$ & $\begin{array}{l}0.78 / \\
13.39\end{array}$ & $\begin{array}{c}4.48 \pm \\
0.62\end{array}$ \\
\hline $\begin{array}{c}\text { T. striatus cv. } \\
\text { Jubileiniy }\end{array}$ & $\begin{array}{l}0.91 / \\
15.11\end{array}$ & $\begin{array}{c}4.92 \pm \\
1.22\end{array}$ & $\begin{array}{l}1.2 / \\
13.09\end{array}$ & $\begin{array}{c}4.97 \pm \\
0.7\end{array}$ & $\begin{array}{l}2.17 / \\
24.87\end{array}$ & $\begin{array}{c}6.52 \pm \\
1.06\end{array}$ & $\begin{array}{l}5.4 / \\
30.59\end{array}$ & $\begin{array}{l}21.21 \pm \\
1.5\end{array}$ & $\begin{array}{l}1.81 / \\
12.71\end{array}$ & $\begin{array}{l}5.23 \pm \\
0.72\end{array}$ \\
\hline
\end{tabular}


Bulavin I. V., Feskov S. A., Brailko V. A., Mitrofanova I. V.

Table 2

Essential oil accumulation in thyme cultivars

\begin{tabular}{ccccc}
\hline Cultivar & \multicolumn{4}{c}{ Essential oil content, (\%)/100g } \\
\cline { 2 - 5 } & \multicolumn{2}{c}{ Fresh weight } & \multicolumn{2}{c}{ Dry weight } \\
\cline { 2 - 5 } & Leaf & Inflorescence & Leaf & Inflorescence \\
\hline Svetliachok & 1.18 & 1.82 & 2.71 & 5.06 \\
\hline Fantazia & $0.1 \pm 0.005$ & $0.41 \pm 0.03$ & $0.28 \pm 0.02$ & $1.36 \pm 0.12$ \\
\hline Jubileiniy & $0.21 \pm 0.02$ & $0.45 \pm 0.01$ & $0.66 \pm 0.06$ & $1.5 \pm 0.03$ \\
\hline
\end{tabular}

A large number of Lamiaceae species inhabits different ecosystems and has a great diversity with a cosmopolitan distribution. The investigated plants, initially, were originated from different regions, however, had similar anatomy: epidermis with cuticle and trichomes, mechanical tissues (collenchyma and sclerenchyma) in stems, inflorescence and leaves. These all were the characteristics of xerophytic plants [8]. For this ecological group, the presence of developed trichomes is usually detected. According to our microscopic observations, non-glandular trichomes, simple and branched, were distinguished on ground tissues of all organs, with smaller amount for stems. It is well known that non-glandular trichomes form a protective barrier against low humidity, high temperatures and sun radiation [9]. Distribution of glandular trichomes was dependent on organ and species. For example, L. angustifolia calyxes were characterized by presence of capitate glandular trichomes with one stalk cell and unicellular ellipsoidal head $(F)$ and glandular trichome with stalk, neck and round secretory cell $(G)$, while stems, inflorescences and bracts predominantly had other types of trichomes. L. intermedia calyxes did not have capitate glandular trichomes with bicellular ovate head $(\mathrm{H})$, however, other vegetative organs formed this type. The presence of one or another type of trichomes may influence on accumulation of secondary metabolites in whole. Histochemically, in Salvia officinalis L., terpenoids, tannins, flavonoids, sesquiterpenic lactones were detected in peltate trichomes, while terpenoids, tannins and flavonoids were revealed in capitate trichomes [10]. We observed differences in accumulation of inclusions with essential oil inside cells of capitate and peltate trichomes. In capitate trichomes, inclusions were clearly differentiated. Probably, this phenomenon associated with a stage of trichome development. It was noticed, that peltate trichomes accumulated essential oil in period of the subcuticular cavity formation [11]. We also noted some variations in the squares of the inclusions with essential oil among organs and species. In general, L. intermedia cv. Temp was characterized by presence of inclusions with greater squares compared with L. angustifolia. Particularly, these differences were clearly visible in calyx tissues. It is well known that $L$. intermedia or lavandin has close composition of essential oil to lavender, however its yield can be exceed 5 times [12].

Among thyme cultivars, essential oil accumulation decreased in the following range: T. mastichina cv. Svetliachok $\rightarrow T$. striatus cv. Jubileiniy $\rightarrow T$. vulgaris cv. Fantazia. Biochemical analysis confirmed the data about the significant biosynthesis of the 
essential oil occurred in the inflorescence. In other vegetative organs, according to anatomical investigation, squares of the inclusions with essential oil varied.

\section{CONCLUSIONS}

1. In vegetative and generative organs as well as in their internal tissues in Lamiaceae plants accumulated inclusions with essential oil.

2. Their amount and squares varied from organ to organ and from species to species.

3. The obtained data can be used in breeding process and on the stage of selection plant material during preparation to molecular analysis.

Investigation was performed in the framework of the State Assignment №0829-20190038 of the FSFIS "NBG-NSC" and done on the base of the Unique Scientific Installation "Scientific Center of Plant Biotechnology, Genomics and Conservation" of the FSFIS "NBG-NSC". L. angustifolia structural investigation was supported by the Russian Science Foundation grant No. 19-76-00023.

\section{References}

1. Abbasova Z. G., Mamedova Z. A., Mamedov R. M. Introdukciya nekotoryh perspektivnyh lekarstvennyh i efiromaslichnyh rastenij v Mardakyanskom dendrarii, Himija rastitel'nogo syr'ja, 1, 121 (2009).

2. Plugatar Yu. V., Shevchuk O. M. Results and directions of the breeding of aromatic and medicinal plants in the Nikitsky Botanical Gardens, Bull. of the State Nikita Botan. Gard., 130, 9 (2019).

3. Marko N. V., Logvinenko L. A., Shevchuk O. M., Feskov S. A. Annotirovannyj katalog aromaticheskih $i$ lekarstvennyh rastenij kollekcii Nikitskogo botanicheskogo sada, 176 p. (IT «ARIAL», Simferopol, 2018).

4. Butnariu M., Sarac I. Essential Oils from Plants, Journal of Biotechnology and Biomedical Science, 1(4), 35 (2018).

5. Birulova E. G., Petrishina N. N., Epidermal structure and anatomy of vegetative organs of Melissa officinalis in connection with essential-oil productivity, Optimization and Protection of Ecosystems, 10, 88 (2014).

6. Isikov V. P., Rabotyagov V. D., Hlypenko L. A., Logvinenko I. E., Logvinenko L. A., Kut'ko S. P., Bakova N. N., Marko N. V. Introduction and selection of aromatic and medicinal cultures: methodological and methodical aspects, 112 p. (NBG-NSC, Yalta, 2009).

7. Hammer O., Harper D. A. T., Ryan P. D. PAST: Paleontological statistics software package for education and data analysis, Palaeontologia Electronica, 4(1), 1 (2001).

8. Orel T. I. Ocenka pochvenno-klimaticheskih resursov s cel'yu vyrashchivaniya lekarstvennyh i efiromaslichnyh rastenij, Likarske roslynnytstvo: Vid dosvidu mynuloho do novitnikh tekhnolohii: Materialy tretoi Mizhnarodnoi naukovo-praktychnoi internet-konferentsii (Poltavs`ka derzhavna agrarna akademiya, Poltava, 2014), p. 64.

9. Tozin L. R.S, Silva de Melo S. C., Rodrigues T. M. Non-glandular trichomes in Lamiaceae and Verbenaceae species: morphological and histochemical features indicate more than physical protection, N.Z. J. Bot., 54(4), 446 (2016).

10. Corsi G., Bottega S. Glandular hairs of Salvia officinalis: new data on morphology, localization and histochemistry in relation to function, Annals of Botany, 84(5), 657 (1999).

11. Razarenova K. N., Babushkina E. V., Smirnov P. D., Kostina O. V., Muravnik L. E., Histochemistry of officinal trichomes representing Lamiaceae family, Medical almanac, 3, 193 (2017).

12. Khokhlov Yu. S., Paly A. E. Comparative characteristics of the basic economic fearures of inter-specific hybrids of the genus lavandula, Plant biology and horticulture: theory, innovation, 2(151), 76 (2019). 
Булавин И. В. Характер накопления эфирного масла у некоторых представителей семейства Lamiaceae / И. В. Булавин, С. А. Феськов, В. А. Браилко, И. В. Митрофанова // Ученые записки Крымского федерального университета им. В. И. Вернадского. Биология, химия. - 2020. - Т. 6 (72), №3. - С. 56-62.

Эфиромасличные растения являются возобновляемым источником сырья, используемого в медицине (фитореабилитация, ароматерапия и др.), производстве парфюмерии и косметики. В Никитском ботаническом саду генофондовая коллекция ароматических и лекарственных растений представлена различными видами, подвидами, формами, сортами и гибридам, что обуславливает необходимость их комплексного анализа. Поэтому целью данного исследования было изучение анатомии органов растений и накопления эфирного масла в них. Материалом служили некоторые виды и сорта семейства Lamiaceae. Исследования анатомии генеративных и вегетативных органов проводили на временных препаратах, изготовленных согласно общепринятым методам; эфирное масло извлекали на аппаратах Гинзберга; данные анализировали статистически с помощью программного обеспечения PAST. Исследуемые растения относились к разным видам, однако имели общие анатомические особенности. В железках и внутренних структурах органов обнаруживали включения с эфирным маслом. Количество и площадь включений, как и процентное содержание эфирного масла, варьировали в зависимости от вида и органа. Полученные данные могут быть использованы в селекционном процессе и на этапе отбора растительного материала при подготовке к молекулярному анализу.

Ключевые слова: Lamiaceae, орган растения, анатомия, накопление эфирного масла. 